\title{
Port Governance and Cruise Tourism
}

\author{
Alejandro Vega-Muñoz ${ }^{1}\left(\mathbb{D}\right.$, Guido Salazar-Sepúlveda ${ }^{2, *} \mathbb{C}$, Nicolás Contreras-Barraza ${ }^{3} \mathbb{C}$ and \\ Lorena Araya-Silva ${ }^{1}$ (D) \\ 1 Public Policy Observatory, Universidad Autónoma de Chile, 7500912 Providencia, Chile; \\ alejandro.vega@uautonoma.cl (A.V.-M.); bella.araya@uautonoma.cl (L.A.-S.) \\ 2 Departamento de Ingeniería Industrial, Facultad de Ingeniería, Universidad Católica de la Santísima \\ Concepción, 4090541 Concepción, Chile \\ 3 Facultad de Economía y Negocios, Universidad Andres Bello, 8370035 Santiago, Chile; \\ nicolas.contreras@unab.cl \\ * Correspondence: gsalazar@ucsc.cl
}

Citation: Vega-Muñoz, A.;

Salazar-Sepúlveda, G.;

Contreras-Barraza, N.; Araya-Silva, L. Port Governance and Cruise Tourism. Sustainability 2021, 13, 4877. https:// doi.org/10.3390/su13094877

Academic Editors: Vítor Caldeirinha, J. Augusto Felício and Ademar Dutra

Received: 27 March 2021

Accepted: 21 April 2021

Published: 27 April 2021

Publisher's Note: MDPI stays neutral with regard to jurisdictional claims in published maps and institutional affiliations.

Copyright: (c) 2021 by the authors. Licensee MDPI, Basel, Switzerland. This article is an open access article distributed under the terms and conditions of the Creative Commons Attribution (CC BY) license (https:// creativecommons.org/licenses/by/ $4.0 /)$.

\begin{abstract}
Cruise activities, until 2020, have presented a significant increase in revenue, as well as number of cruises and passengers transported, and it has become a challenge for ports to respond to this demand for services. In response to this, the world's ports have implemented different governance models. In this context, in this paper, we aim to review the different governance models, as well as port cooperation, competition, and stakeholders. For this purpose, using science metric meta-analysis, an article set is extracted that strictly refers to the governance model of two databases integrated into the Core Collection Web of Science, whose selection process is polished with the PRISMA guidelines, establishing the eligibility criteria of studies using PICOS tool, to which a qualitative meta-analysis is applied. A limited studies set is identified, that includes governance model implementations, private strategies and internalization patterns in the port sector and cruise ships, patterns of port cooperation and governance, governance models in cruise ports, structures and strategies, and changes in the cruise market. Finally, various governance model forms are determined, all documented in the scientific research worldwide, discussing the various components of study topics.
\end{abstract}

Keywords: blue economy; seaport; cruise terminal; stakeholder; cooperation; competition; tourism; cruise ship

\section{Introduction}

In this paper, we aim to identify port system governance models that incorporate cruise tourism, cruise ship operations, cruise terminals, or passenger interactions as one of its strategic elements.

Cruise tourism is a service industry with a high-level of service quality [1], which involves all aspects of the economy and society [2] and has become an industry that significantly contributes to the tourism economy globally [3]. Revenues from this market amount to USD 134 billion annually, making it one of the fastest growing and most financially promising sectors of the tourism industry [4]. Between 2009 and 2019, the number of ocean cruise passengers worldwide increased from 17.8 million to 30 million passengers, and North American passengers make up most cruisers [5,6]. The rapid growth of the cruise industry and its effects on all the services involved in its itineraries, port development, and related services represent an opportunity to contribute to the economic development of the places and countries visited, but also to highlight its effects on sustainable environmental and social development $[7,8]$. In this regard, the Cruise Line International Association (CLIA) notes that cruise tourism generated, in 2017, an estimated circulating movement of USD 134 billion in total production of goods and services globally, generating an increase of $6.3 \%$ as compared with that in 2016 [3,4]. Given this, $1,108,676$ jobs were generated with an $8.5 \%$ increase over that in 2016 , and people employed in these jobs 
received USD 45.6 billion in revenue, an 11\% increase over that in 2016 [9]. More recently, in 2019, these figures reached 1,166,000 jobs estimated at USD 50.5 billion in wages and salaries, generating a total global output of USD 154.5 billion. The effect of the COVID-19 pandemic, from mid-March through September 2020, generated losses of USD 77 billion in global economic activity and 518,000 jobs equivalent to USD 23 billion in wages [10].

As we have already pointed out, until 2020, cruise tourism was the fastest growing sector within the tourism industry [2]. However, due to COVID-19 pandemic in March 2020, due to health indications and governmental restrictions, cruise lines stopped operations and suspended their travels. Thus, the COVID-19 pandemic with government measures such as global mobility restrictions, port closures, and health socialization measures, found a cruise industry very unprepared to deal with the countless effects of this pandemic, from operational and health policies to overall business management, and which have led to an unprecedented crisis in cruise tourism [11]. All this has led to a very significant financial and value loss of major cruise lines resulting in a wide ranged collapse in the total value of the assets of the main cruise lines, i.e., the Royal Caribbean Cruises lines' shares fell by $82.31 \%$, and the Norwegian Cruise Line Holdings shares fell by $85.17 \%$. Another example is Carnival where its shares in Corporation \& Plc fell by $76.61 \%$ from 2 January 2020 to 23 March 2020 [12,13]. However, all of this has generated a reaction in the industry by developing action plans to revive its operations with strengthened new management systems and cost controls.

\section{Background Literature}

\subsection{Port Governance Modeling}

The challenges in port governance have focused on the effects on the surrounding territorial economy based on logistic services and integration with other modes of transport, an increase in public-private participation in ports, and an increase in the added value of services through port and port terminal performance assessment systems [14-17].

The findings of these assessments confirm that decisions depending on the trajectory of local/national systems, generate asymmetry of implementation when different countries seek generic governance solutions. Therefore, these results confirm the existence of different types of port governance models, which to some extent correspond to the hypothetical typology according to which port authorities may be conservative, facilitating, or entrepreneurial. Differences are mainly defined by geographical location and condition and governance practices between small and large ports [18-20].

By observing the implementation process of some of these models documented in mainstream academic publications, we are addressing various situations. In the Netherlands, corporatization has involved transforming state agencies into majority state-owned enterprises, such as what happened in the Port of Rotterdam, where comparing two periods showed significant improvements in all performance indicators [21]. In the case of the Portuguese government, the policies adopted in port management had different effects, causing both operations and port labor to be more productive [22]. For its part, port governance in France has changed recently, with the place of the State being the supervision of delegated ports and large seaports [23]. In the Brazilian port sector, its functions were reformulated to the National Council for the Integration of Transport Policy with decentralization of national port planning [24].

Port governance also involves considering spatial structure and information systems necessary for a mix between operational efficiency and commercial efficiency [25]. Additionally, finding the appropriate cooperation and competencies models requires a reflective effort that incorporates the stakeholders needed to not produce tariff wars and to attach governance models in coherence with territorial government systems [26,27]. This is relevant because within the same country there can be various port governance models, which can affect the mechanisms and port performance factors and their margin and profitability [28,29]. 
Finally, for Ferrari et al. [30] and Cao [25], the challenges of port governance models are to introduce a dynamic approach to fares that guarantees benefits to both the terminal operator and the Port Authority. In order to save on port energy and reduce emissions, the most fundamental objective is to establish a long-term strategy for the development of green ports.

\subsection{Effects of Competition and Cooperation on Port Governance}

Increased competition due to the consolidation of the shipping industry has resulted in the tasks of port authorities being one of the factors that can contribute to the competitiveness of a port [31-35]. Among these actions, Knatz studied [36] improvement efforts carried out by the U.S. government through capital injection, giving greater participation to agencies, changes in favor of port maintenance taxes, and a strengthening of port performance reports.

Another of the actions carried out according to De Langen et al. [21] was corporatization (restructuring or transformation of a state-owned asset or organization into a corporation), resulting in positive effects on performance in Rotterdam ports, as well as being a hallmark in port development in China [37]. In the case of Asia, Japanese ports have played a dual role, managing maritime terminals and, at the same time, developing the maritime front of their port cities for multi-purposes [38].

It is important that the institutional frameworks that have been implemented in the port reforms of different localities do not cause asymmetry in the institutional capacity at the local and national level and in the actions that they can carry out with other ports [18,39-43]. In addition, another key aspect is that governance analysis should include formal governance agreements, and also the ability and willingness to implement appropriate instruments to regulate the market, sustainable development, and human capital, and therefore maximize the economic well-being or material living conditions [44-49] (p. 27 [49]).

Improved performance and competitiveness of ports are also part of stakeholder challenges, which require a configuration aimed at responding to the external operating environment, strategies, and structures of the port organization. Moreover, the challenges are how to assess the impact of reforms, achieve systemic coordination within complex port systems, and implement market-oriented strategies [50-54].

Long-term port strategic planning must be based on the real inclusion of stakeholders, including civil society, so that it can act as a catalyst for the change of governance in the external and internal port system, being a boost to the evolution of administrative and ownership structures [55-59]. More operationally, considerations regarding the governance of commonly used infrastructure are important, in a political context that favors private ownership and liberalization of the transport sector, as well as combining global challenges with local claims [60-62].

\section{Methods}

The selected cases were identified using Preferred Reporting Items for Systematic Reviews and Meta-Analyses (PRISMA) guidelines [63], complemented with PICOS tool determining the eligibility criteria for articles (Population, Interventions, Comparators, Outcomes, and Study designs, PICOS) [64], using the thematic proximity of Solé et al. [65] publication about ecosystem services assessment in coastal areas as a methodological reference. The initial search for articles was strengthened with scientometrics [66] and the use of VOSviewer (Centre for Science and Technology Studies, Leiden University, Leiden, The Netherlands) [67], which has been used recently in topics related to this study by Alexandridis et al. [68], Ducruet et al. [69], Munim et al. [70], and Vega-Muñoz et al. [7]. Since scientometrics as a meta-analysis [71] focusses on knowledge production, spatiality of knowledge production, and knowledge relationships among the network of global actors [72,73], the initial selection of articles was refined based on a search vector using field labels, wildcards, and operators (Boolean, proximity, and priority) [74], 
and its incorporation of sequentially mixed use with PRISMA, has also been addressed previously [75-77].

Articles were identified with the search vector TS $=((P O R T$ NEAR/0 GOVERNANCE $)$ AND (touris* OR cruis $^{*}$ OR passenger $\left.{ }^{*}\right)$ ), using the following 5 databases from the Web of Science Core Collection (WoS): Science Citation Index Expanded (SCIE), Social Sciences Citation Index (SSCI), Emerging Sources Citation Index (ESCI), Conference Proceedings Citation Index-Science (CPCI-S), and Conference Proceedings Citation Index-Social Science and Humanities (CPCI-SSH). First, SCIE and SSCI, both contain journals indexed to the WoS Journal Citation Report (JCR), and are considered to be high-quality journals on which their impact is calculated annually based on the average citations received. Then, ESCI contributes articles that are published in journals without impact calculations but adds other publications originating in regions where knowledge production develops with less intensity and is recognized within the periphery and semi-periphery of the knowledge production [78]. Finally, the databases of Conference Proceedings (CPCI-S and CPCI-SSH) provide recent knowledge that has not yet been published in journals, but which is already part of the discussion in prestigious international conferences. Regarding Scopus, the journals indexed to SSCI-WoS have a high indexation duplicity in Scopus, but the Scopus journals do not present a double indexing with the SSCI base, and therefore these have not been considered because "Scopus covers a superior number of journals but with lower impact and limited to recent articles" [79] (p. 24).

Using PRISMA, the selection of articles based on eligibility criteria was specified as: population under study, interventions in this population, comparator elements of these studies, results to which these studies are oriented, and study designs, a set of criteria called PICOS tool (see Table 1).

Table 1. Eligibility criteria (PICOS).

\begin{tabular}{|c|c|}
\hline PICOS & Description \\
\hline Population & $\begin{array}{l}\text { Port systems or port authorities (only seaports and maritime ports, } \\
\text { included ports in inland waterways) }\end{array}$ \\
\hline Interventions & $\begin{array}{c}\text { Analysis, proposal, implementation, or evaluation of governance } \\
\text { models that consider cruise traffic }\end{array}$ \\
\hline Comparator & $\begin{array}{c}\text { Port governance models that consider to some extent tourism, cruise } \\
\text { ship operations, or their passengers (tourists, cruise passengers), in } \\
\text { their analysis, design, implementation, or evaluation }\end{array}$ \\
\hline Outcomes & $\begin{array}{c}\text { Broad spectrum results, around the port governance studies } \\
\text { considering to some extent the traffic of cruise ships in the port } \\
\text { system or port authority in study }\end{array}$ \\
\hline Study designs & Quantitative, qualitative, and mixed study types are included. \\
\hline
\end{tabular}

A qualitative review of the content of the articles selected in PRISMA and PICOS was used, and the following variables were considered: key frameworks, dimensions and relevant variables, methodology, and the governance model identified or addressed in each case. The information was summarized in a sequential time-ordered table of port governance models incorporating cruise traffic on the basis of empirical categorizations, the description of cases of governance models, and the identification of models based on the results presented by the authors, if they did not expressly refer to a specific governance model.

\section{Results}

The scientometric search of articles identified a total of six documents from two databases in the Core Collection Web of Sciences (SSCI and SCIE). There were six unique titles and abstracts and there were six full-text articles recovered to apply a screening with selectivity criteria defined in PICOS for which it was not relevant to consider exclusions. 
Thus, the screening results in six articles fulfilled our inclusion criteria, as observed in Figure 1.
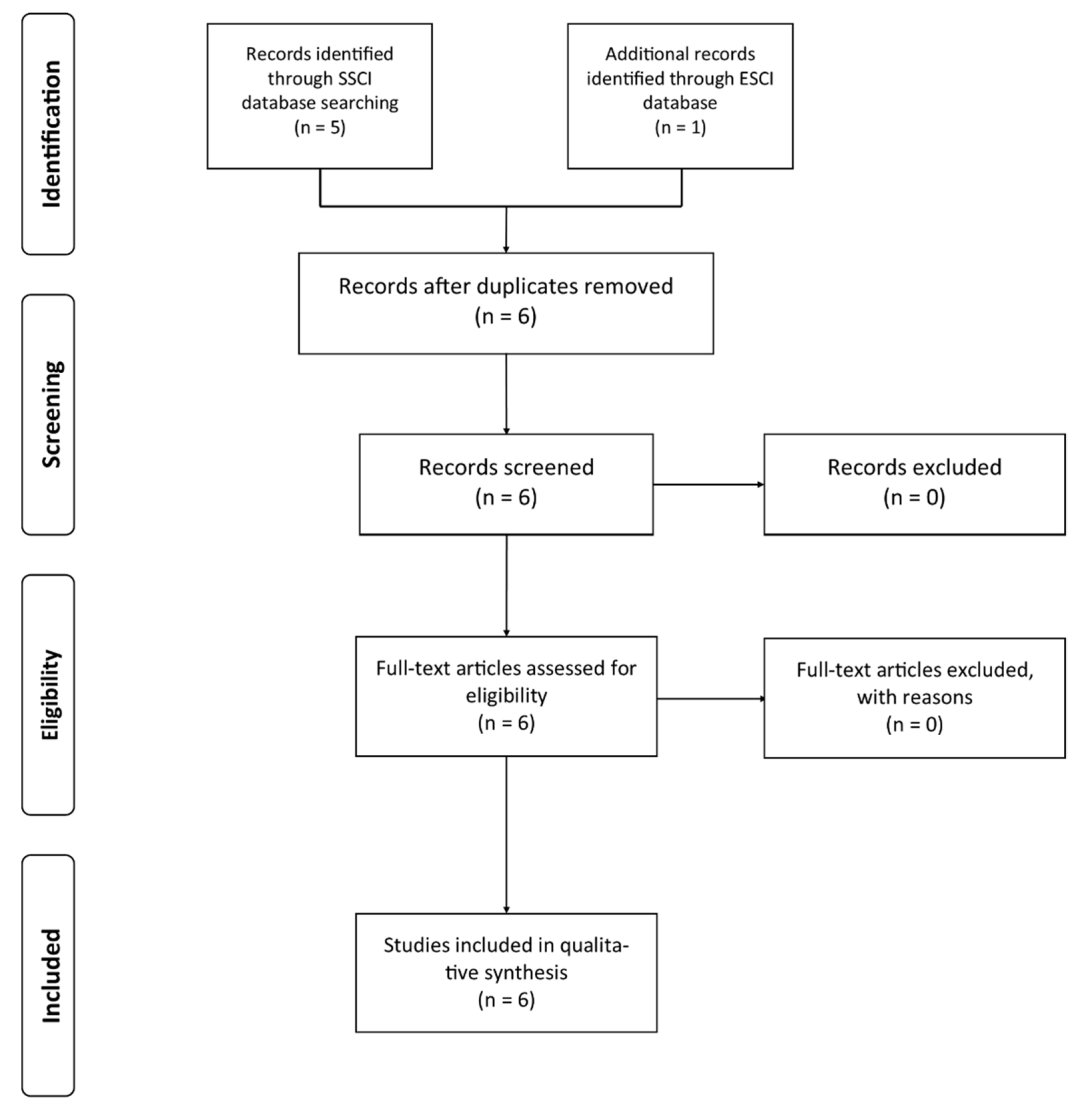

Figure 1. PRISMA analysis flow.

Qualitative Review Analysis

The resulting six articles following the application of eligibility criteria were reviewed at a full-text level, to accurately define whether their characteristics provided homogeneity criteria that made them comparable. Table 2 presents the main identification and recovery information from the WoS databases.

Table 2. Articles included for the qualitative review analysis.

\begin{tabular}{|c|c|c|c|c|c|}
\hline Ref. & First Author & Journal & Publ. Year & Affiliation Author & WoS Category and DOI ${ }^{1}$ \\
\hline [80] & $\begin{array}{c}\text { Pallis, A.A.; } \\
\text { Papachristou, A.A. }\end{array}$ & $\begin{array}{l}\text { Transp. Rev. } \\
\text { IF: 6.704, Q1 }\end{array}$ & $\begin{array}{l}\text { Early } \\
\text { Acces }\end{array}$ & Univ Aegean (Greece) & $\begin{array}{c}\text { Transportation, } \\
10.1080 / 01441647.2020 .1857884\end{array}$ \\
\hline [81] & $\begin{array}{c}\text { Corluka, G.; Peronja, I.; } \\
\text { Tubic, D. }\end{array}$ & $\begin{array}{l}\text { Nase More } \\
\text { IF: Not appl. }\end{array}$ & 2020 & $\begin{array}{l}\text { Univ Split (Croatia), and Coll } \\
\text { Tourism \& IT Management } \\
\text { Virovitica (Croatia). }\end{array}$ & $\begin{array}{l}\text { Engineering, Marine, } \\
\text { 10.17818/NM/2020/3.1 }\end{array}$ \\
\hline [82] & $\begin{array}{l}\text { Pallis, A.A.; Arapi, K.P.; } \\
\text { Papachristou, A.A. }\end{array}$ & $\begin{array}{l}\text { Marit. Policy Manag. } \\
\text { IF: 3.152, Q2 }\end{array}$ & 2019 & Univ Aegean (Greece) & $\begin{array}{c}\text { Transportation, } \\
10.1080 / 03088839.2019 .1590657\end{array}$ \\
\hline [83] & Shinohara, M.; Saika, T. & $\begin{array}{l}\text { Res. Transp. Bus. } \\
\text { Manag. } \\
\text { IF: } 2.189, \text { Q3 }\end{array}$ & 2018 & Univ Fukuchiyama (Japan) & $\begin{array}{c}\text { Business, Management, } \\
\text { Transportation, } \\
\text { 10.1016/j.rtbm.2018.02.009 }\end{array}$ \\
\hline [84] & $\begin{array}{l}\text { Pallis, A.A.; Parola, F.; } \\
\text { Satta, G.; } \\
\text { Notteboom, T.E. }\end{array}$ & $\begin{array}{l}\text { Marit. Econ. Logist. } \\
\text { IF: 1.703, Q3 }\end{array}$ & 2018 & $\begin{array}{l}\text { Univ Aegean (Greece), Univ } \\
\text { Genoa (Italy), and Shanghai } \\
\text { Maritime Univ (China). }\end{array}$ & $\begin{array}{c}\text { Transportation, } \\
10.1057 / \text { s41278-017-0091-7 }\end{array}$ \\
\hline [85] & $\begin{array}{l}\text { Panayides, P.M.; } \\
\text { Lambertides, N.; } \\
\text { Andreou, C. }\end{array}$ & $\begin{array}{l}\text { Res. Transp. Bus. } \\
\text { Manag. } \\
\text { IF: } 2.189, \text { Q3 }\end{array}$ & 2017 & Cyprus Univ Technol (Cyprus) & $\begin{array}{c}\text { Business, Management, } \\
\text { Transportation, } \\
\text { 10.1016/j.rtbm.2016.10.002 }\end{array}$ \\
\hline
\end{tabular}


Table 2 shows a high presence of institutions mainly from Mediterranean Europe in five articles (Cyprus, Croatia, Italy, and Greece), and Asia in two articles (China and Japan). Thus, a greater presence of the University of the Aegean (Greece), independently, as well as in connection with institutions in China and Italy. In terms of thematic coverage, the six articles are mainly associated with the transportation-WoS category. The data and metadata of the articles are processed with VOSviewer [67], first detecting how they intertwined through a time series of auto-cites the studies by Pallis et al. $[80,82,84]$, as the first two studies [80,82] are also cited by Corluka et al. [81] (see Figure 2). Secondly, there are many references that are cited together in these studies (co-citation), that is, two or more studies are used simultaneously as references for one or more studies (see Figure 3). Although it can be presumed that the common references among the three studies by Pallis et al. $[80,82,84]$ explain this, Figure 4 clarifies that there is also a bibliographic coupling (common references) between the studies by Pallis et al. $[80,82,84]$ and the other three studies $[81,83,85]$.

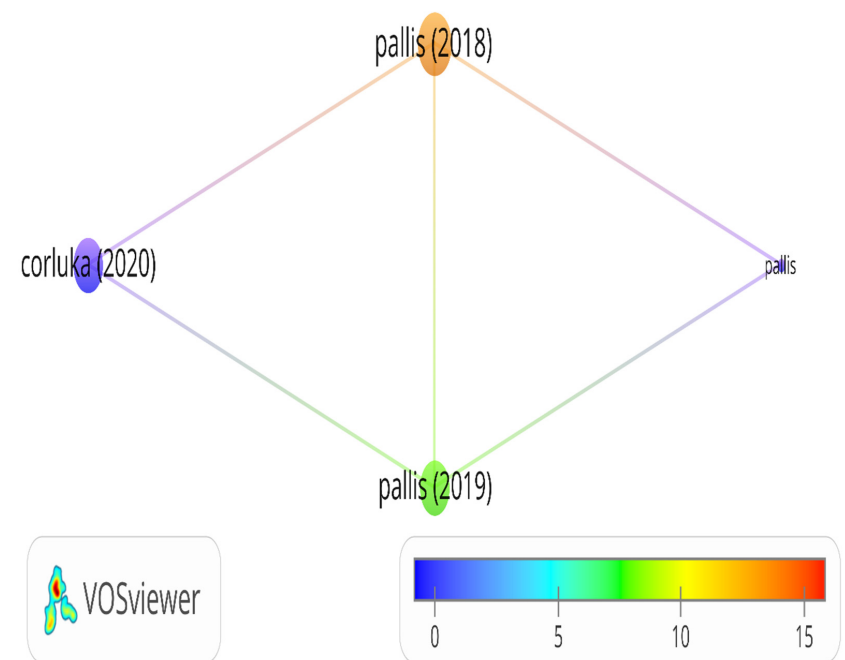

Figure 2. Cross-citation relational graph.

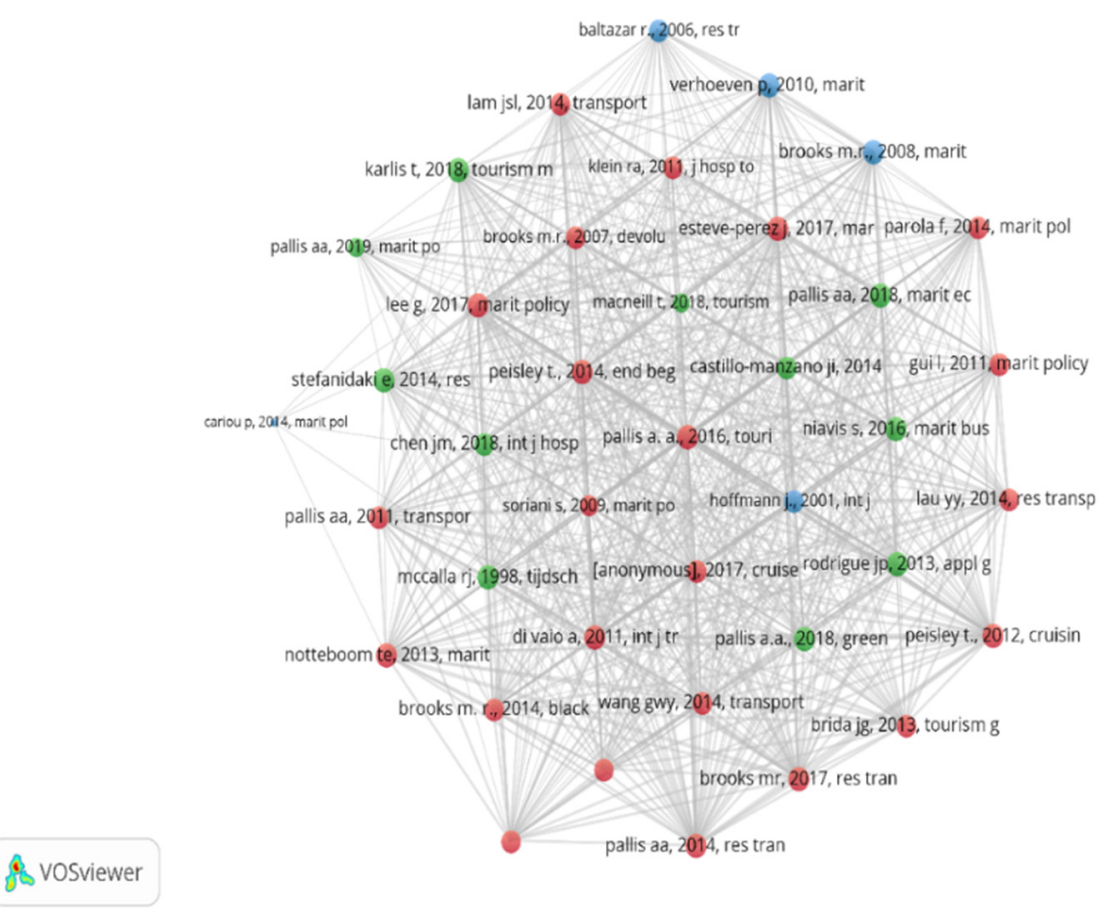

Figure 3. Co-citation relational graph. 


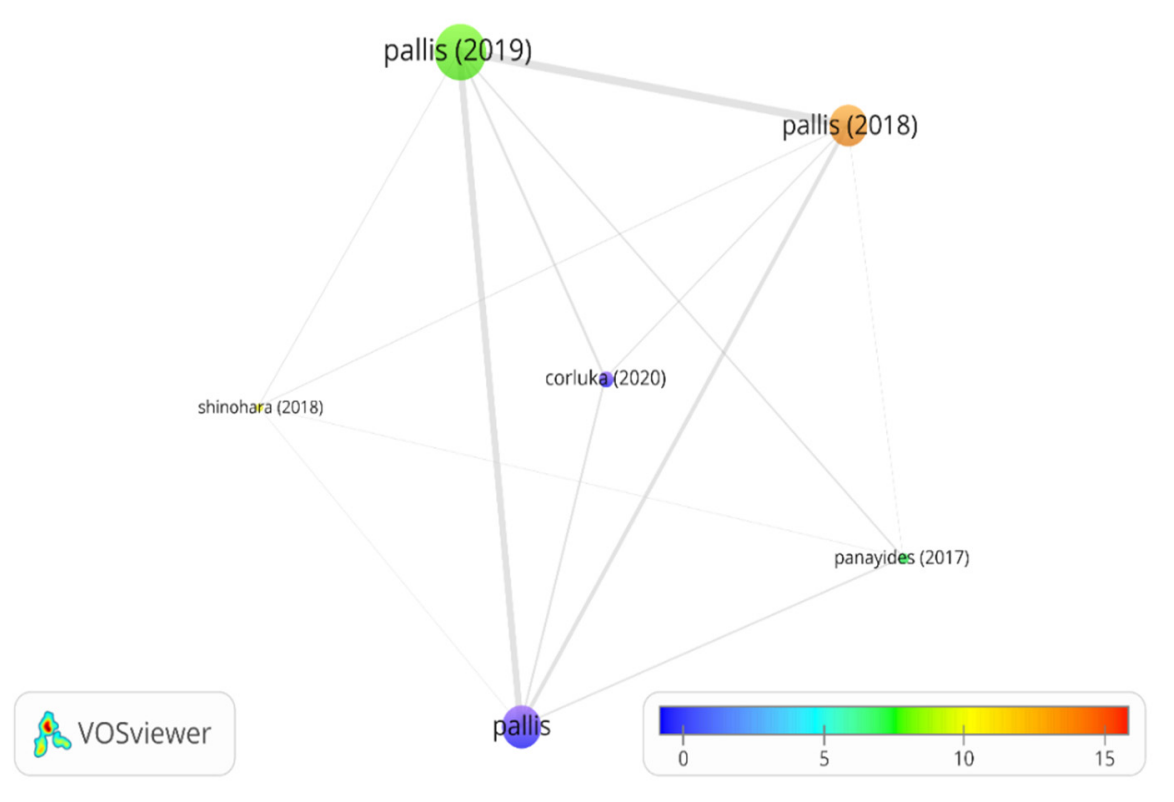

Figure 4. Bibliographic coupling relational graph.

Figure 2 represents the relational graph of quotations between the set of six articles, the size and color of the spheres indicates the number of total quotes received by these articles in the Web of Science Core Collection.

The arcs between nodes in the relational network show the simultaneous use of these references, which shows a dense connection between them, by colors (network, blue, and green) the three clusters of references that are densely connected to each other are indicated, and the thickness of the arcs indicates the intensity of the relationship.

Figure 4 shows the relational graph that links its references to the set of six articles, the thickness of the arcs between nodes indicates the intensity of the relationship, and the size and color of the spheres indicate the total number of cites received by these articles in the Web of Science Core Collection. The connections resulting from the set of references connecting Pallis et al. $[80,82,84]$ and the other three articles $[81,83,85]$ are presented in Table 3.

Table 3. Included articles for the qualitative review analysis.

\begin{tabular}{cl}
\hline $\begin{array}{c}\text { Articles Referentially Connected } \\
\text { with Pallis et al. [76,78,80] }\end{array}$ & $\begin{array}{c}\text { Cited Reference in Each Article (Only First Author and } \\
\text { Sorted Alphabetically) }\end{array}$ \\
\hline & Castillo-Manzano J.I., 2014, Transport Res E-Log [86] \\
& Chen J.M., 2018, Int J Hosp Manag [87] \\
& Macneill T., 2018, Tourism Manage [88] \\
& Pallis A.A., 2014, Res Transp Bus Manag [89] \\
& Pallis A.A., 2016, Tourismos [90] \\
& Pallis A.A., 2018, Marit Econ Logist [84] \\
& Pallis A.A., 2019, Marit Policy Manag [82] \\
Corluka et al. (2020) & Rodrigue J.P., 2013, Appl. Geogr [91] \\
& Soriani S, 2009, Marit Policy Manag [92] \\
& Baltazar R., 2006, Res Transp Econ [93] \\
& Brooks M.R., 2008, Marit Policy Manag [94] \\
& Cariou P., 2014, Marit Policy Manag [95] \\
& Hoffmann J., 2001, Int J Maritime Ec [96] \\
& Verhoeven P., 2010, Marit Policy Manag [16] \\
\hline Panayides et al. (2017) & Brooks M.R., 2017, Res Transp Bus Manag [97] \\
& Cariou P., 2014, Marit Policy Manag [95] \\
& Notteboom T.E., 2013, Marit Policy Manag [98] \\
\hline
\end{tabular}


These sets of references provide knowledge regarding how the amount of cruise traffic in a port system is interrelated with its infrastructure of attention, the development of the local port city, and its 'hinterland' and sustainability in its surroundings. Furthermore, to promote the understanding of governance models (and port policies) as the framework for the establishment of comprehensive port assessment and performance measures, as well as port management in harmony with stakeholders, in awareness of the capabilities and limitations of port operation and the structure and culture of internal organization of the port. Finally, they support the conceptualization of port governance as a way to respond to the current challenges of the global cruise industry.

Below, Table 4 contains the results of the qualitative systematization of the articles identified in Table 2. These articles address the issue of port reforms, the implementation of the governance model in Cyprus [85]; private strategies and internationalization patterns in the port and cruise sector [84]; port cooperation and governance patterns in Japan [83]; governance models in cruise ports, structures, and strategies [82]; port industry patterns and operation models governance in cruise port [81]; and finally, pre pandemic challenges in the European market cruise [80].

Table 4. Qualitative meta-analysis of cruise port governance studies a

\begin{tabular}{|c|c|c|c|c|}
\hline Authors/Topics & Key Framework & Dimensions/Variables & Methodology & Government Model \\
\hline Panayides et al. 2017 & $\begin{array}{l}\text { Port reforms and } \\
\text { implementation of } \\
\text { port governance }\end{array}$ & $\begin{array}{l}\text { Trends of framework in } \\
\text { responsibilities } \\
\text { Supervisory board } \\
\text { Advisory board } \\
\text { Board of directors }\end{array}$ & $\begin{array}{l}\text { Description and analysis } \\
\text { of governance structure of } \\
\text { the Cyprus Port Authority } \\
\text { and Limasol Port }\end{array}$ & $\begin{array}{l}\text { Governance model for the } \\
\text { port of Limassol proposal }\end{array}$ \\
\hline Pallis et al. 2018 & $\begin{array}{l}\text { Private entry strategies } \\
\text { Internationalization } \\
\text { Forms of entry } \\
\text { Emerging partnerships }\end{array}$ & $\begin{array}{c}\text { Who? } \\
\text { Why? } \\
\text { When? } \\
\text { Where? } \\
\text { Which way? }\end{array}$ & $\begin{array}{l}\text { Empirical study of the } \\
\text { forms of entry and } \\
\text { emerging partnerships in } \\
\text { the cruise terminal } \\
\text { business }\end{array}$ & Private operator model \\
\hline Shinohara 2018 & $\begin{array}{l}\text { Cooperation patterns } \\
\text { Economic cluster } \\
\text { Port manager with } \\
\text { innovative connectivity }\end{array}$ & $\begin{array}{c}\text { Cooperation } \\
\text { Coordination } \\
\text { Integration } \\
\text { Geographical position } \\
\text { Port Origin } \\
\text { Location } \\
\text { Infrastructure } \\
\text { Construction }\end{array}$ & $\begin{array}{l}\text { Description of } \\
\text { multifaceted port } \\
\text { governance study of Japan } \\
\text { ports management with } \\
\text { cooperative methods }\end{array}$ & Suruga Bay Port' model \\
\hline Pallis et al. 2019 & $\begin{array}{c}\text { Cruise port industry pattern } \\
\text { Cruise port model of } \\
\text { operation governance } \\
\text { Contextual changes } \\
\text { Triangle of relationship } \\
\text { configuration }\end{array}$ & $\begin{array}{l}\text { Port Type } \\
\text { Port Location } \\
\text { Port Structure } \\
\text { Port Strategy }\end{array}$ & $\begin{array}{c}\text { Empirical study, based in } \\
\text { CATPCA }\end{array}$ & 4 Port governance models \\
\hline Pallis et al. 2019 & $\begin{array}{l}\text { Cruise port industry pattern } \\
\text { Basic types of port operation } \\
\text { Grow of industry } \\
\text { Cruise lines strategics }\end{array}$ & $\begin{array}{c}\text { Types of port } \\
\text { Geographically } \\
\text { concentration } \\
\text { Cruise flows } \\
\text { Performing cruise ports } \\
\text { Market position } \\
\text { Dominant position } \\
\text { Growth rate of cruises }\end{array}$ & $\begin{array}{l}\text { Comparative study of port } \\
\text { governance models and } 4 \\
\text { research questions for } \\
\text { empirical approach }\end{array}$ & $\begin{array}{l}\text { Ports without private entry } \\
\text { in port operation model } \\
\text { Ports with private entry in } \\
\text { port operation model }\end{array}$ \\
\hline Pallis 2021 (EA) & $\begin{array}{c}\text { European cruise } \\
\text { ports transition } \\
\text { Trend of long-term cruise } \\
\text { port strategies }\end{array}$ & $\begin{array}{c}\text { Type of challenge } \\
\text { ST, strategic } \\
\text { O, operational } \\
\text { S, societal } \\
\text { E, environmental }\end{array}$ & $\begin{array}{l}\text { Empirical analysis of } \\
\text { structural changes in the } \\
\text { European port industry }\end{array}$ & $\begin{array}{l}\text { North Europe port Model } \\
\text { Med Port Model }\end{array}$ \\
\hline
\end{tabular}

${ }^{\text {a }}$ For more details see Appendix A. 
The above systematization identifies port governance models such as the governance model for the port of Limassol proposal that transitions from a public operation model to one without losing control of operations and property (a landlord model), and incorporates elements such as concessions gradually, resulting in greater development and growth in the port community and the incorporation of elements of competition. On the contrary, the Suruga Bay Port model incorporates the logic of cooperation, coordination, and integration of the bay port area, and the 'hinterland' integration, sea area and land, aerial, and maritime transport networks with a clear definition of the support/safety/spark roles that allow a fast reaction to natural disasters and coordination of activities between the three positions included under this governance approach.

The private operator model, four port governance models, and ports without/with private entry in port operation models, refer to a growing entry of private actors into the operation of at least some port operation functions, which depends on the type of port and the growing interests of various actors to participate in the growing crossover market, at least until the prepandemic era. These models are oriented to competition and cooperation or integration, and it can be observed that there is greater globalization of their operations together with the development of innovative strategies enabling access to economies of scale. Finally, the North Europe Port model and Med Port model correspond to management models identified from challenges that the cruise industry has faced in recent years. They differ in the location of their ports and the maturity of the cruise market. These dimensions both determine the degree of conflict and pressure of the greatest challenges identified in the Pallis et al. [80] study, implying that the cruise ports or cruise terminals of northern Europe, due to their smaller size, are less stressed unlike cruise ports or cruise terminals in the Mediterranean, in which their larger size involves more complex strategies, interaction with various types of actors, and new cruise market demands. This may seem contradictory, given that port systems in northern Europe, considering all types of ship traffic, often exceed the size and complexity of Mediterranean ports.

\section{Discussion and Conclusions}

From historical institutionalist logic [99], the activities of a port authority are important to international port competitiveness, and therefore it is relevant that proper governance promotes coordination, cooperation, and inter-port competition [32].

The systematization of port governance models, presented in this article, establishes some patterns of empirical and theoretical understanding that apply to greater integration of actors, diversification of strategies, and openness to private investors in line with recent analyses of the cruise sector and its future trends [100]. Thus, we understand, in this study, that the role of a port authority is reduced to regulation, coordination, and in cases where the authority is an entrepreneur, to the development of strategies that incorporate market mechanisms into port management without surrendering port ownership.

However, in terms of practical interest, the entry of new port operators such as cruise lines operating globally under business alliances, as has been observed in recent years [4,9], suggests further privatization of port activity for this traffic type, and its touristic, hospitality, and leisure areas of influence. This can only contribute effectively to the development of destination locations, if an appropriate strategy of integration between the activities on board cruise ships, in the port, and in the tourist attractions is considered, generating new business opportunities, as illustrated in the recent study by Mangano et al. [101]. It is also clear from our work that the predominance of competition among ports is over unless it is operated in a regional and/or global way. Therefore, it is important to highlight the cooperation, coordination, and integration model of the Japanese case since competition does not occur between the ports of the integrated operating system, but with other ports abroad [83].

The pandemic has imposed challenges such as the situation faced by ports and operators in the Mediterranean and the North Sea, where the port industry with some dedication to cruise ships is changing itself in search of new operating strategies, given an industry 
that has been presenting relevant strategic and operational changes given a modernization of passenger demand [3], change of infrastructure, and internationalization of operations. Although tensions are greater in the ports of greater "maturity" and size in the tourism market, prepandemic challenges realized a need to establish strategies to interact with the different actors that have entered the industry and the business environment given the emergence of variables such as the minimization of environmental impact and local development of adjacent zones to a port area.

Future research should expand and deepen this type of study, given the lack of mainstream articles that address port governance with in-depth consideration of cruise traffic, even though this type of maritime transport is related to a breadth of economic, social, and environmental aspects [7]. Although future challenges post the COVID-19 pandemic have not yet clearly observed cruise ships have been in the eye of the hurricane of this global crisis [12], the relationship with the communities of interaction in each landfall should be studied in more detail, in each of the aspects that may deteriorate, as the receptivity climate towards passengers, in this sense studies such as García et al. [102] can be an example of new research optics. In addition to this, we find it necessary to expand the geographical area of the studies, since the breadth of destinations covered by the cruise industry is not limited only to Europe and some of Asia's major countries. Gutberlet's study [103] gave a good account of this need to recognize, analyze, evaluate, and attempt to propose solutions in various realities around cruise ships and their participation in port systems of various latitudes. These same future research challenges show that the main weakness of this study is the extremely limited number of studies in this regard, all recently published and that do not give centrality in the models specifically exposed to the cruise industry, which prevents a greater basis of analysis of previous experiences, as well as longitudinal coverage of experiences on which long-term results can be observed. As governance studies on maritime transport for tourism purposes continue to expand, it will become increasingly easy to understand the relationship between cruise ships and the governance structure of the port systems that host them, being able to make a greater contribution of this activity to the blue economy.

Author Contributions: Conceptualization, A.V.-M.; methodology, A.V.-M. and L.A.-S.; software, A.V.-M.; validation, N.C.-B., formal analysis, G.S.-S., L.A.-S., N.C.-B. and A.V.-M.; data curation, A.V.-M.; writing-original draft preparation, G.S.-S., N.C.-B. and L.A.-S.; writing-review and editing, A.V.-M.; project administration, A.V.-M.; funding acquisition, G.S.-S., N.C.-B. and A.V.-M. All authors have read and agreed to the published version of the manuscript.

Funding: The APC was partially funded by the Universidad Católica de la Santísima Concepción.

Institutional Review Board Statement: Not applicable.

Informed Consent Statement: Not applicable.

Data Availability Statement: Data sharing not applicable. No new data were created or analyzed in this study. The qualitative meta-analysis used the dois in the Table 2: 10.1080/01441647.2020.1857884, 10.17818/NM/2020/3.1, 10.1080/03088839.2019.1590657, 10.1016/j.rtbm.2018.02.009, 10.1057/s41278017-0091-7, 10.1016/j.rtbm.2016.10.002.

Conflicts of Interest: The authors declare no conflict of interest. 


\section{Appendix A}

Table A1. Governance model description.

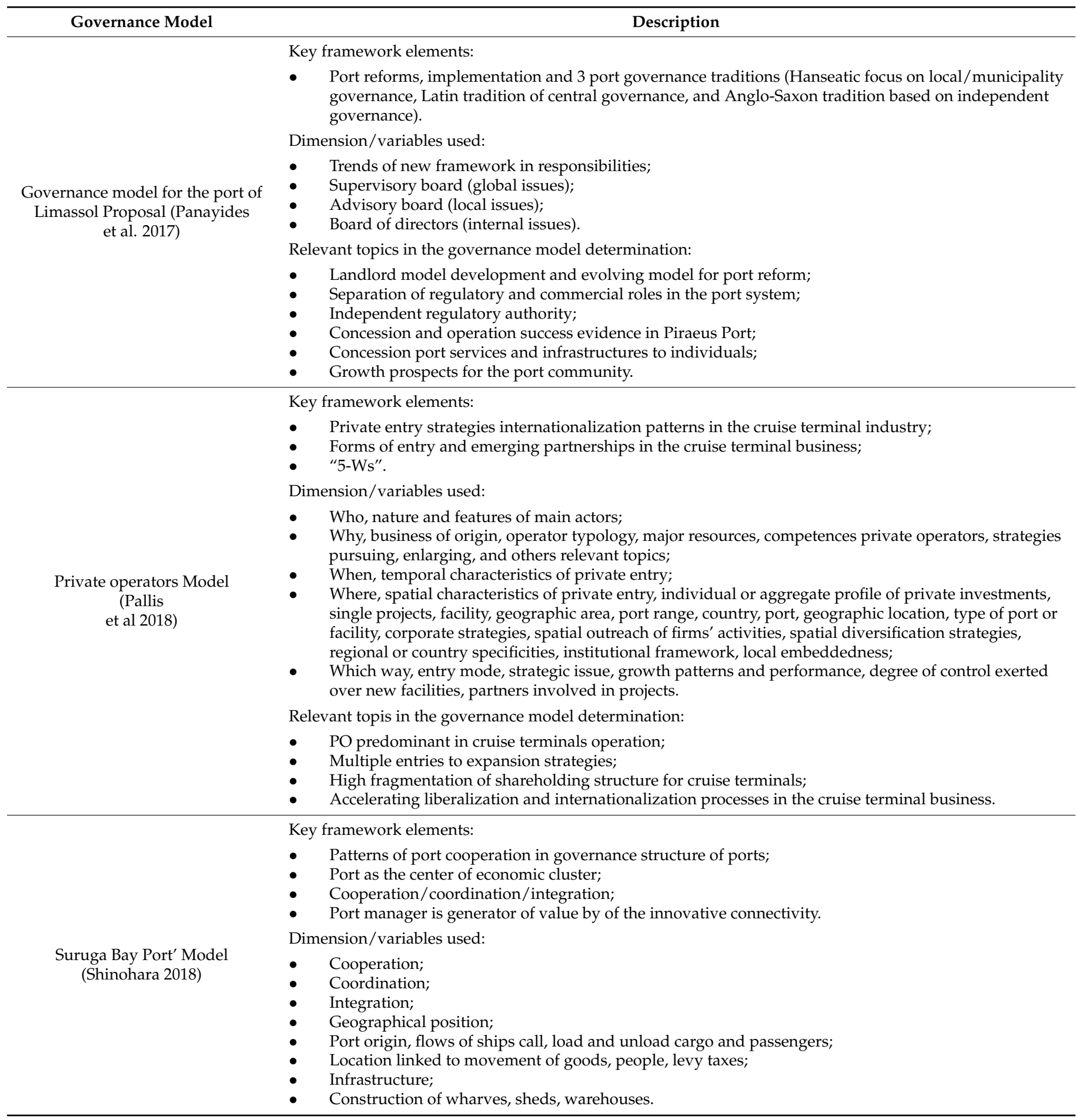


Table A1. Cont.

\begin{tabular}{|c|c|}
\hline Governance Model & Description \\
\hline $\begin{array}{l}\text { Suruga Bay Port' Model } \\
\text { (Shinohara 2018) }\end{array}$ & $\begin{array}{l}\text { Relevant topics in the governance model determination: } \\
\text { - } \quad \text { Cooperative and complementary framework and evolving implementation; } \\
\text { - } \quad \text { major prefectural ports, i.e., Shimizu, Tagonoura, and Omaezaki; } \\
\text { - } \quad \text { Functe a logistical hub linked with economic prefecture development; } \\
\quad \text { logistic and industry; } \\
\text { - Safety linked with disaster prevention and response; } \\
\text { - Spark linked with tourism, travel, and environment; } \\
\quad \text { Smart Port Suruga Bay and its holistic network. }\end{array}$ \\
\hline $\begin{array}{l}4 \text { Port Governance Models } \\
\text { (Pallis et al. 2019) }\end{array}$ & $\begin{array}{l}\text { Key framework elements: } \\
\text { - } \quad \text { Cruise port industry pattern; } \\
\text { - } \quad \text { Cruise port model of operation governance; } \\
\text { - } \quad \text { Triangle of relationship configuration of environment/strategy/structure. } \\
\text { Dimension/variables used: } \\
\text { - } \quad \text { Port type, size, function in itinerary, attractiveness of the ports, number of existing cruise terminals; } \\
\text { - } \quad \text { Port location, country port and geographical region; } \\
\text { - } \quad \text { Port structure, development of cruise port responsible and cruise port operation responsible; } \\
\quad \text { collaboration and partnerships, berth allocation (BA) policy, airport services at Port/ISO certification, } \\
\text { Relevant topics in the governance model determination: } \\
\text { - } \quad \text { Model A, large Port, PA operation, active leadership/entrepreneur; } \\
\text { - Model B, ICTO operation, the investor, facilitator; } \\
\text { - Model C, TO operation, the marketer; } \\
\text { Model D, small port, PA operation, the passive, conservator. }\end{array}$ \\
\hline $\begin{array}{l}\text { Ports with private entry in port } \\
\text { operation Model } \\
\text { Ports without private entry in port } \\
\text { operation Model } \\
\text { (Ćorluka et al. 2020) }\end{array}$ & $\begin{array}{l}\text { Key framework elements: } \\
\text { - } \quad \text { Cruise port industry pattern; } \\
\text { Basic types of port operation; } \\
\text { - } \quad \text { Faster grow of industry; } \\
\text { Dimension/variables used: } \\
\text { - } \quad \text { Types of ports, without private entry in port operation/with private entry in port operation; } \\
\text { - } \quad \text { Geographically concentration of ports; } \\
\text { - } \quad \text { Market position respect passenger flows; } \\
\text { - } \quad \text { Dominant position of cruise ports in ports of large cruisers \& greater number of cruise passengers per } \\
\text { call; } \\
\text { Relevant topics in the governance model determination: } \\
\text { - } \quad \text { Port with private entry, no geographically concentrated, decreased operation, less market share, annual } \\
\text { growing cruise passenger numbers and rate of cruise ship calls; } \\
\text { Port without private entry, dispersed all over cruising regions, no geographically concentrated, } \\
\text { decreasing cruise ship calls, higher growth rate of cruise passengers per call, primary market role, large } \\
\text { cruisers ports. }\end{array}$ \\
\hline
\end{tabular}


Table A1. Cont.

\begin{tabular}{|c|c|}
\hline Governance Model & Description \\
\hline \multirow{6}{*}{$\begin{array}{l}\text { North Europe port Model } \\
\text { Med Port Model } \\
\text { (Pallis } 2021 \text { (EA)) }\end{array}$} & Key framework elements: \\
\hline & $\begin{array}{l}\text { - } \quad \text { European cruise ports in transition; } \\
\text { - } \quad \text { Srend of long-term cruise port strategies; } \\
\text { global port holdings. }\end{array}$ \\
\hline & Dimension/variables used: \\
\hline & $\begin{array}{l}\text { - According to type of challenge, strategic, operational, societal, environmental; } \\
\text { - } \quad \text { Empirical analysis of structural changes in the European port industry. }\end{array}$ \\
\hline & Relevant topics in the governance model determination: \\
\hline & $\begin{array}{l}\text { - North Europe port model, few challenges stand, bigger vessels, relationships with cruise } \\
\text { lines/people/businesses around the port, relationship with cruise lines, exploiting potential of winter } \\
\text { cruising, relationship with city of arrival/local authorities; } \\
\text { Med port model, bigger size port, matured Mediterranean market, more challenges like relationships } \\
\text { with cruise lines (tense), relationships with people/businesses around the port (complex), security, } \\
\text { infrastructure (other than transport) in the port, connectivity of the destination with source markets. }\end{array}$ \\
\hline
\end{tabular}

\section{References}

1. Yoon, Y.; Cha, K.C. A Qualitative Review of Cruise Service Quality: Case Studies from Asia. Sustainability $2020,12,8073$. [CrossRef]

2. Perea, M.; Rosa, J.; Andrade, M. Potential of public transport in regionalisation of main cruise destinations in Mediterranean. Tour. Manag. 2019, 74, 382-391. [CrossRef]

3. Arasli, H.; Saydam, M.B.; Kilic, H. Cruise Travelers' Service Perceptions: A Critical Content Analysis. Sustainability 2020, $12,6702$. [CrossRef]

4. Cruise Line Industry Association. Cruise Trends and Industry Outlook. 2019. Available online: https://cruising.org/-/media/ research-updates/research/clia-2019-state-of-the-industry (accessed on 16 March 2021).

5. Radić, A.; Popesku, J. Quality of cruise experience: Antecedents and consequences. Teme 2018, 42, 523-539.

6. Radić, A.; Lück, M.; Al-Ansi, A.; Chua, B.-L.; Seeler, S.; Raposo, A.; Kim, J.J.; Han, H. To Dine, or Not to Dine on a Cruise Ship in the Time of the COVID-19 Pandemic: The Tripartite Approach towards an Understanding of Behavioral Intentions among Female Passengers. Sustainability 2021, 13, 2516. [CrossRef]

7. Vega-Muñoz, A.; Arjona-Fuentes, J.M.; Ariza-Montes, A.; Han, H.; Law, R. In search of 'a research front' in cruise tourism studies. Int. J. Hosp. Manag. 2020, 85, 102353. [CrossRef]

8. Vega-Muñoz, A.; Salazar-Sepulveda, G.; Espinosa-Cristia, J.F.; Sanhueza-Vergara, J. How to Measure Environmental Performance in Ports. Sustainability 2021, 13, 4035. [CrossRef]

9. Cruise Line Industry Association. Cruise Trends and Industry Outlook. 2018. Available online: https://cruising.org/-/media/ CLIA/Research/Global\%202018\%20EIS (accessed on 16 March 2021).

10. Cruise Line Industry Association. State of the Cruise Industry Outlook 2021. Available online: https://cruising.org/en/newsand-research/research/2020/december/state-of-the-cruise-industry-outlook-2021 (accessed on 19 April 2021).

11. Zhang, X.; Wang, C. Prevention and Control of COVID-19 Pandemic on International Cruise Ships: The Legal Controversies. Healthcare 2021, 9, 281. [CrossRef]

12. Radić, A.; Law, R.; Lück, M.; Kang, H.; Ariza-Montes, A.; Arjona-Fuentes, J.M.; Han, H. Apocalypse Now or Overreaction to Coronavirus: The Global Cruise Tourism Industry Crisis. Sustainability 2020, 12, 6968. [CrossRef]

13. Nasdaq. Stocks. 2020. Available online: https://www.nasdaq.com/market-activity/stocks (accessed on 16 March 2021).

14. Laxe, F.G. Port governance: Main trends. Rev. Econ. Mund. 2008, 18, 355-368.

15. Verhoeven, P. European ports policy: Meeting contemporary governance challenges. Marit. Policy Manag. 2009, 36, 79-101. [CrossRef]

16. Verhoeven, P.A. Review of port authority functions: Towards a renaissance? Marit. Policy Manag. 2010, 37, 247-270. [CrossRef]

17. Vieira, J.; Fialho, G.O.M. Port management modernization and integrated operational planning. Rev. Eletronica Estrateg. Neg. 2020, 13, 196-224. [CrossRef]

18. Ng, A.K.Y.; Pallis, A.A. Port governance reforms in diversified institutional frameworks: Generic solutions, implementation asymmetries. Environ. Plan. A 2010, 42, 2147-2167. [CrossRef]

19. Verhoeven, P.; Vanoutrive, T.A. quantitative analysis of European port governance. Marit. Econ. Logist. 2012, 14, 178-203. [CrossRef]

20. Vieira, G.B.B.; Neto, F.J.K.; Amaral, F.G. Governance, Governance Models and Port Performance: A Systematic Review. Transp. Rev. 2014, 34, 645-662. [CrossRef]

21. De Langen, P.W.; Heij, C. Corporatisation and Performance: A Literature Review and an Analysis of the Performance Effects of the Corporatisation of Port of Rotterdam Authority. Transp. Rev. 2014, 34, 396-414. [CrossRef] 
22. Caldeirinha, V.; Felicio, J.A.; da Cunha, S.F. Government policies and Portuguese port governance in the period from 2005 to 2015. Res. Transp. Bus. Manag. 2017, 22, 11-20. [CrossRef]

23. Debrie, J.; Lacoste, R.; Magnan, M. From national reforms to local compromises: The evolution of France's model for port management, 2004-2015. Res. Transp. Bus. Manag. 2017, 22, 114-122. [CrossRef]

24. Cutrim, S.S.; Botter, R.C.; Robles, L.T. Proposal for a new port governance model for Brazil. Rev. Eletronica Estrateg. Neg. 2018, 11, 200-221. [CrossRef]

25. Cao, L.L. Changing Port Governance Model: Port Spatial Structure and Trade Efficiency. J. Coast. Res. 2020, 963-968. [CrossRef]

26. Pallis, A.A.; Syriopoulos, T. Port governance models: Financial evaluation of Greek port restructuring. Transp. Policy 2007, 14, 232-246. [CrossRef]

27. Castillo-Manzano, J.I.; Asencio-Flores, J.P. Competition between New Port Governance Models on the Iberian Peninsula. Transp. Rev. 2012, 32, 519-537. [CrossRef]

28. Caldeirinha, V.R.; Felicio, J.A.; Da Cunha, S.F.; Da Luz, L.M. The nexus between port governance and performance. Marit. Policy Manag. 2018, 45, 877-892. [CrossRef]

29. Munim, Z.H.; Saeed, N.; Larsen, O.I. Tool port' to landlord port': A game theory approach to analyse gains from governance model transformation. Marit. Policy Manag. 2019, 46, 43-60. [CrossRef]

30. Ferrari, C.; Puliafito, P.P.; Tei, A. Dynamics in terminal concessions: The role of performances. Marit. Econ. Logist. 2019, 21, 99-110. [CrossRef]

31. Munim, Z.H.; Sornn-Friese, H.; Dushenko, M. Identifying the appropriate governance model for green port management: Applying Analytic Network Process and Best-Worst methods to ports in the Indian Ocean Rim. J. Clean Prod. 2020, $268,122156$. [CrossRef]

32. Van de Voorde, E.; Verhoeven, P. The economics of port authority reform a framework for ex-post evaluation. Int. J. Transp. Econ. 2014, 41, 297-325.

33. Chiu, R.H.; Yen, D.C. Application of organizational life cycle theory for port reform initiatives in Taiwan. Res. Transp. Bus. Manag. 2015, 14, 14-24. [CrossRef]

34. Kearney, A.; Harrington, D.; Kelliher, F. Executive capability for innovation: The Irish seaports sector. Eur. J. Train. Dev. 2018, 42, 342-361. [CrossRef]

35. Wang, Z.P.; Yao, D.Q.; Yue, X.H.; Liu, J.J. Impact of IT Capability on the Performance of Port Operation. Prod. Oper. Manag. 2018, 27, 1996-2009. [CrossRef]

36. Knatz, G. How competition is driving change in port governance, strategic decision-making and government policy in the United States. Res. Transp. Bus. Manag. 2017, 22, 67-77. [CrossRef]

37. Guan, C.Q.; Yahalom, S. China's Port Reform and Development Policy Analysis. Transp. Res. Rec. 2011, 1-9. [CrossRef]

38. Inoue, S. Realities and challenges of port alliance in Japan-Ports of Kobe and Osaka. Res. Transp. Bus. Manag. 2018, 26, 45-55. [CrossRef]

39. Wilmsmeier, G.; Sanchez, R.J. Evolution of national port governance and interport competition in Chile. Res. Transp. Bus. Manag. 2017, 22, 171-183. [CrossRef]

40. Merkel, A. Spatial competition and complementarity in European port regions. J. Transp. Geogr. 2017, 61, 40-47. [CrossRef]

41. Koliousis, I.G.; Papadimitriou, S.; Riza, E.; Stavroulakis, P.J.; Tsioumas, V. Strategic correlations for maritime clusters. Transp. Res. Part A Policy Pract. 2019, 120, 43-57. [CrossRef]

42. Santiago, J.I.P.; Orive, A.C.; Cancelas, N.G. DEA-Bootstrapping Analysis for Different Models of Spanish Port Governance. J. Mar. Sci. Eng. 2021, 9, 30. [CrossRef]

43. Wang, K.; Ng, A.K.Y.; Lam, J.S.L.; Fu, X.W. Cooperation or competition? Factors and conditions affecting regional port governance in South China. Marit. Econ. Logist. 2012, 14, 386-408. [CrossRef]

44. Monios, J. Geographies of governance in the freight transport sector: The British case. Transp. Res. Part A Policy Pract. 2019, 121, 295-308. [CrossRef]

45. Satta, G.; Maugeri, S.; Panetti, E.; Ferretti, M. Port labour, competitiveness and drivers of change in the Mediterranean Sea: A conceptual framework. Prod. Plan. Control 2019, 30, 1102-1117. [CrossRef]

46. Zhao, C.P.; Li, R.; Wang, Y.C.; Yu, H.; Gong, Y. Study on the propagation of sustainable development concept among Gulf ports based on complex network. Marit. Policy Manag. 2020, 1-19. [CrossRef]

47. Dong, G. Optimization of the Pricing Strategies between Container Terminals under Deregulation. Math. Probl. Eng. 2018, 2018, 1626429. [CrossRef]

48. Wu, S.H.; Yang, Z.Z. Analysis of the case of port co-operation and integration in Liaoning (China). Res. Transp. Bus. Manag. 2018, 26, 18-25. [CrossRef]

49. OECD. Economic well-being. In OECD Framework for Statistics on the Distribution of Household Income, Consumption and Wealth; OECD Publishing: Paris, France, 2013.

50. Tseng, P.H.; Pilcher, N. Port governance in Taiwan: How hypocrisy helps meet aspirations of change. Res. Transp. Bus. Manag. 2017, 22, 38-48. [CrossRef]

51. Gjerding, A.N.; Kringelum, L.B. Systemic coordination of organizational roles: The importance of relational capital in port governance. Res. Transp. Bus. Manag. 2018, 28, 77-84. [CrossRef] 
52. Zhang, Q.; Zheng, S.Y.; Geerlings, H.; El Makhloufi, A. Port governance revisited: How to govern and for what purpose? Transp. Policy 2019, 77, 46-57. [CrossRef]

53. Gocer, A.; Vural, C.A.; Deveci, D.A. Drivers of and barriers against market orientation: A study of Turkish container ports. Marit. Econ. Logist. 2019, 21, 278-305. [CrossRef]

54. Meyiwa, A.; Chasomeris, M. South Africa's port doctrine: Dilemmas and the way forward. Marit. Stud. 2020, 19, 179-191. [CrossRef]

55. Dooms, M.; Verbeke, A.; Haezendonck, E. Stakeholder management and path dependence in large-scale transport infrastructure development: The port of Antwerp case (1960-2010). J. Transp. Geogr. 2013, 27, 14-25. [CrossRef]

56. Aerts, G.; Dooms, M.; Haezendonck, E. Stakeholder management practices found in landlord seaport authorities in Flanders: An inside-out perspective. Int. J. Shipp. Transp. Logist. 2015, 7, 597-620. [CrossRef]

57. Witte, P.; Wiegmans, B.; Braun, C.; Spit, T. Weakest link or strongest node? Comparing governance strategies for inland ports in transnational European corridors. Res. Transp. Bus. Manag. 2016, 19, 97-105. [CrossRef]

58. Song, D.W.; Lee, S.W. Port governance in Korea: Revisited. Res. Transp. Bus. Manag. 2017, 22, 27-37. [CrossRef]

59. Chen, J.H.; Fei, Y.J.; Lee, P.T.W.; Tao, X.Z. Overseas Port Investment Policy for China's Central and Local Governments in the Belt and Road Initiative. J. Contemp. China 2019, 28, 196-215. [CrossRef]

60. Monios, J. Port governance in the UK: Planning without policy. Res. Transp. Bus. Manag. 2017, 22, 78-88. [CrossRef]

61. Parola, F.; Ferrari, C.; Tei, A.; Satta, G.; Musso, E. Dealing with multi-scalar embeddedness and institutional divergence: Evidence from the renovation of Italian port governance. Res. Transp. Bus. Manag. 2017, 22, 89-99. [CrossRef]

62. Carlan, V.; Heaver, T.; Sys, C.; Vanelslander, T. Oil spill response in port areas: Governance and the polluter-pays principle. Int. J. Transp. Econ. 2018, 45, 367-391. [CrossRef]

63. Moher, D.; Liberati, A.; Tetzlaff, J.; Altman, D.G.; The PRISMA Group. Preferred Reporting Items for Systematic Reviews and Meta-Analyses: The PRISMA Statement. PLoS Med. 2009, 6, e1000097. [CrossRef]

64. Methley, A.M.; Campbell, S.; Chew-Graham, C.; McNally, R.; Cheraghi-Sohi, S. PICO, PICOS and SPIDER: A comparison study of specificity and sensitivity in three search tools for qualitative systematic reviews. BMC Health Serv. Res. 2014, 14, 579. [CrossRef]

65. Solé, L.; Ariza, E.A. Wider view of assessments of ecosystem services in coastal areas: The perspective of social-ecological complexity. Ecol. Soc. 2019, 24. [CrossRef]

66. Porter, A.L.; Kongthon, A.; Lu, J.C. Research profiling: Improving the literature review. Scientometrics 2002, 53, 351-370. [CrossRef]

67. Van Eck, N.J.; Waltman, L. Software survey: VOSviewer, a computer program for bibliometric mapping. Scientometrics 2010, 84, 523-538. [CrossRef]

68. Alexandridis, G.; Kavussanos, M.G.; Kim, C.Y.; Tsouknidis, D.A.; Visvikis, I.D. A survey of shipping finance research: Setting the future research agenda. Transp. Res. Part E Logist. Transp. Rev. 2018, 115, 164-212. [CrossRef]

69. Ducruet, C.; Panahi, R.; Ng, A.K.Y.; Jiang, C.M.; Afenyo, M. Between geography and transport: A scientometric analysis of port studies in Journal of Transport Geography. J. Transp. Geogr. 2019, 81, 102527. [CrossRef]

70. Munim, Z.H.; Saeed, N. Seaport competitiveness research: The past, present and future. Int. J. Shipp. Transp. Logist. 2019, 11, 533-557. [CrossRef]

71. Kullenberg, C.; Kasperowski, D. What Is Citizen Science?-A Scientometric Meta-Analysis. PLoS ONE 2016, 11, e0147152.

72. Mikhaylov, A.; Mikhaylova, A.; Hvaley, D. Knowledge Hubs of Russia: Bibliometric Mapping of Research Activity. J. Scientometr. Res. 2020, 9, 1-10. [CrossRef]

73. Albort-Morant, G.; Henseler, J.; Leal-Millán, A.; Cepeda-Carrión, G. Mapping the Field: A Bibliometric Analysis of Green Innovation. Sustainability 2017, 9, 1011. [CrossRef]

74. Vega-Muñoz, A.; Arjona-Fuentes, J.M. Social Networks and Graph Theory in the Search for Distant Knowledge in the Field of Industrial Engineering. In Advanced Applications of Graph Theory in Modern Society; Pal, M., Samanta, S., Pal, A., Eds.; IGI-Global: Hershey, PA, USA, 2020; pp. 397-418.

75. Kazerani, M.; Davoudian, A.; Zayeri, F.; Soori, H. Assessing abstracts of Iranian systematic reviews and meta-analysis indexed in WOS and Scopus using PRISMA. Med. J. Islam. Repub. Iran 2017, 31, 104-109. [CrossRef]

76. Sott, M.K.; Furstenau, L.B.; Kipper, L.M.; Giraldo, F.D.; Lopez-Robles, J.R.; Cobo, M.J.; Zahid, A.; Abbasi, Q.H.; Imran, M.A. Precision Techniques and Agriculture 4.0 Technologies to Promote Sustainability in the Coffee Sector: State of the Art, Challenges and Future Trends. IEEE Access 2020, 8, 149854-149867. [CrossRef]

77. Carlucci, S.; De-Simone, M.; Firth, S.K.; Kjærgaard, M.B.; Markovic, R.; Rahaman, M.S.; Annaqeeb, M.K.; Biandrate, S.; Das, A.; Dziedzic, J.W.; et al. Modeling occupant behavior in buildings. Build. Environ. 2020, 174, 106768. [CrossRef]

78. Oliveira, T. Scientific policies in the knowledge age: A conjuncture analysis of the global scientific ecosystem. Perspect. Ciênc. Inf. 2019, 24, 191-215. [CrossRef]

79. Chadegani, A.A.; Salehi, H.; Yunus, M.M.; Farhadi, H.; Fooladi, M.; Maryam Farhadi, M.; Nader Ale Ebrahim, N.A. A Comparison between Two Main Academic Literature Collections: Web of Science and Scopus Databases. Asian Soc. Sci. 2013, 9, 18-26. [CrossRef]

80. Pallis, A.A.; Papachristou, A.A. European Cruise ports: Challenges since the pre-pandemic era. Transp. Rev. 2021. (Accepted, Early Access). [CrossRef]

81. Corluka, G.; Peronja, I.; Tubic, D. Cruise Port Passenger Flow Analysis: A Cruise Port Governance Perspective. Nase More 2020, 67, 181-191. [CrossRef] 
82. Pallis, A.A.; Arapi, K.P.; Papachristou, A.A. Models of cruise ports governance. Marit. Policy Manag. 2019, 46, 630-651. [CrossRef]

83. Shinohara, M.; Saika, T. Port governance and cooperation: The case of Japan. Res. Transp. Bus. Manag. 2018, 26, 56-66. [CrossRef]

84. Pallis, A.A.; Parola, F.; Satta, G.; Notteboom, T.E. Private entry in cruise terminal operations in the Mediterranean Sea. Marit. Econ. Logist. 2018, 20, 1-28. [CrossRef]

85. Panayides, P.M.; Lambertides, N.; Andreou, C. Reforming public port authorities through multiple concession agreements: The case of Cyprus. Res. Transp. Bus. Manag. 2017, 22, 58-66. [CrossRef]

86. Castillo-Manzano, J.I.; Fageda, X.; Gonzalez-Laxe, F. An analysis of the determinants of cruise traffic: An empirical application to the Spanish port system. Transport. Res. Part E 2014, 66, 115-125. [CrossRef]

87. Chen, M.J.; Nijkamp, P. Itinerary planning: Modeling cruise lines' length of stay in ports. Int. J. Hosp. Manag. 2018, 73, 55-63. [CrossRef]

88. Macneill, T.; Wozniak, D. The economic, social, and environmental impact of cruise tourism. Tour. Manag. 2018, 66, 387-404. [CrossRef]

89. Pallis, A.A.; Rodrigue, J.P.; Notteboom, T.E. Cruises and Cruise Ports: Structures and Strategies. Res. Transp. Bus. Manag. 2014, 13, 1-5. [CrossRef]

90. Pallis, A.A.; Arapi, K.P. A multi-port cruise region: Dynamics and hierarchies in the Med. Tourism 2016, 11, 168-201.

91. Rodrigue, J.P.; Notteboom, T. The geography of cruises: Itineraries, not destination. Appl. Geogr. 2013, 38, 31-42. [CrossRef]

92. Soriani, S.; Bertazzon, S.; Cesare, F.D.; Rech, G. Cruising in the Mediterranean: Structural aspects and evolutionary trends. Marit. Policy Manag. 2009, 36, 235-251. [CrossRef]

93. Baltazar, R.; Brooks, M.R. Port governance, devolution and the matching framework: A configuration theory approach. Res. Transp. Econ. 2006, 17, 379-403. [CrossRef]

94. Brooks, M.R.; Pallis, A.A. Assessing port governance models: Process and performance components. Marit. Policy Manag. 2008, 35, 411-443. [CrossRef]

95. Cariou, P.; Fedi, L.; Dagnet, F. The new governance structure of French seaports: An initial post-evaluation. Marit. Policy Manag. 2014, 41, 430-443. [CrossRef]

96. Hoffmann, J. Latin American ports: Results and determinants of private sector participation. Int. J. Marit. Econ. 2001, 3, $221-241$. [CrossRef]

97. Brooks, M.; Cullinane, K.; Pallis, A. Revisiting port governance and port reform: A multi-country examination. Res. Transp. Bus. Manag. 2017, 22, 1-10. [CrossRef]

98. Notteboom, T.; Pallis, A.; de Langen, P.; Papachristou, A. Advances in port studies: The contribution of 40 years Maritime Policy \& Management. Marit. Policy Manag. 2013, 40, 636-653. [CrossRef]

99. Pierson, P.; Skocpol, T. Historical Institutionalism in Contemporary Political Science. Rev. Urug. Cienc. Política 2008, 17, 7-38. Available online: http:/ / rucp.cienciassociales.edu.uy/index.php/rucp/article/view/216 (accessed on 16 March 2021).

100. Lau, Y.Y.; Yip, T.L. The Asia cruise tourism industry: Current trend and future outlook. Asian J. Shipp. Logist. 2020, 36, 202-213. [CrossRef]

101. Mangano, S.; Ugolini, G.M. New Opportunities for Cruise Tourism: The Case of Italian Historic Towns. Sustainability 2020, 12, 4616. [CrossRef]

102. Garcia, C.; Mestre-Runge, C.; Morán-Tejeda, E.; Lorenzo-Lacruz, J.; Tirado, D. Impact of Cruise Activity on Freshwater Use in the Port of Palma (Mallorca, Spain). Water 2020, 12, 1088. [CrossRef]

103. Gutberlet, M. They just buy a karak and leave-Overtourism in Souq Muttrah, the Sultanate of Oman. Z. Tour. 2020, 12, 221-246. [CrossRef] 